\title{
What Motivates Street-level Bureaucrats to Implement the Reforms of Elected Politicians?
}

\author{
Don S. Lee \\ University of Nottingham \\ don.lee@,nottingham.ac.uk \\ Soonae Park \\ Seoul National University \\ psoonae@snu.ac.kr
}

Accepted in Policy \& Politics on 23 July 2020

\begin{abstract}
The aim of this article is to explore the motivations of street-level bureaucrats when implementing change initiated by elected politicians. We analyse experimental data on more than 1,800 local civil servants from all 243 local governments in South Korea and find that street-level bureaucrats are more likely to implement change instigated by local elected politicians when their own policy positions are reflected in the reforms. Moreover, the degree to which street-level bureaucrats are likely to execute reforms instigated by local politicians is greater when bureaucrats perceive themselves as having more freedom to exercise discretion. These findings reveal a behavioural insight into the conditions in which bureaucrats are more likely to respond to change championed by elected politicians versus conditions where they are more likely to follow existing rules in the policy implementation process.
\end{abstract}

Keywords: Street-level Bureaucrats; Bureaucratic Discretion; Behavioural Public Policy; Survey Experiment, Policy Implementation, Local Government, South Korea, Reforms 
Bureaucratic organisations are often expected to run according to rules (Crozier, 1964; Weber, 1974). Political science research has offered optimistic views regarding political control of the bureaucracy by focusing on how to control bureaucrats rather than on whether to control them. An extensive literature on political control of the bureaucracy discusses mechanisms of delegation and accountability from inside and outside the bureaucracy and highlights the role of principals rather than that of agents (e.g., McCubbins and Schwartz, 1984; Epstein and O'Halloran, 1999; Huber and Shipan, 2002; Lee, 2020). However, what actually happens on the agent side of the principal-agent relationship, particularly on the frontline, seems to deviate from the political control arguments.

In reality, public employees on the frontline are in a position where they intrinsically exert discretion in policy implementation. Lipsky's (1980/2010) seminal work suggests that the discretion granted to street-level bureaucrats (SLBs) and their relative autonomy from principals create room to be filled by their own decisions which, in turn, are influenced by street-level factors. Although elected politicians do play a role in changing agency policies and influencing policy outcomes (Scholz and Wood, 1998; Lewis, 2008; Lee and Park, 2020), public administrative research has provided limited evidence of political influences on the actions of SLBs (Brehm and Gates, 1997; Riccucci et al, 2004; Riccucci, 2005). In a word, since Lipsky's observation of SLBs' behaviour, this view has been well accepted by subsequent research.

The main question is, then, what impacts SLBs' decisions? An extensive literature on SLBs' implementation of policy has examined a variety of factors, ranging from bureaucrats' attitudes and knowledge concerning their tasks (Sandfort, 2000; Meyers and Vorsanger, 2003), the characteristics of the implementing organisations (Lynn, Heinrich, and Hill, 2000; Hill and Lynn, 2004; Brodkin, 2007, 2011), to contextual factors related to workloads and external pressures (May and Winter, 2009). Regarding political factors, although their 
influence over SLBs' implementation is found to be relatively muted, it is still important to understand why there is variation in the extent to which SLBs respond to their elected politicians across individuals in a given institutional context. Recent research particularly illuminates the centrality of bureaucratic discretion in actual implementation of policy change (e.g., Tummers and Bekkers, 2014; Miller and Whitford, 2016; Thomann et al, 2018). Extending the research, we investigate conditions where SLBs are more responsive to elected politicians' policy change versus those where they are more likely to abide by existing rules in local governments' policy implementation.

Building on the theories of SLBs' implementation and the relationship between elected politicians and SLBs, we examine how the congruence of political ideology between governors/mayors and SLBs and the degree of discretion SLBs perceive affect the implementation of these politicians' new policy or policy change. ${ }^{1}$ To test our hypotheses proposed below, we employ a unique survey design of a list experiment which leverages indirect questioning techniques and integrate a field experimental aspect by conducting the surveys at SLBs' workplaces.

Analysing original data on more than 1,800 local civil servants from all 243 provincial and municipal governments in South Korea, gathered as part of a representative survey, we find that SLBs' policy positions and their perception of discretion indeed significantly affect their implementation decisions. SLBs are more likely to implement their elected politicians' policy change when the latter's political ideology is more congruent with their own than when it is incongruent, controlling for several characteristics of governors/mayors and bureaucrats. Furthermore, the treatment effects - the degree to which

\footnotetext{
${ }^{1}$ We use political ideology, policy positions, policy views, and policy dispositions interchangeably as they are conceptually close to each other.
} 
SLBs intend to execute the elected politicians' policy change - are greater when SLBs perceive higher levels of discretion in policy implementation.

South Korea is a useful case to test whether local bureaucrats will abide by existing rules made by the central government or choose to use their discretion in applying elected local politicians' policy change, given the central government's control over local governments but with room for local bureaucrats' discretion on the frontline. Since 1995, provincial governors and municipal mayors have been directly elected as local agency heads every four years. The adoption of local executive elections meant the beginning of establishing a local self-government system. However, while provincial governors and municipal mayors are granted the authority to enact rules and ordinances, such power is limited because the scope of rules and ordinances made by them cannot take precedence over the laws and implementation ordinances made by the central government. Moreover, local governments are legally and financially dependent on the central government, as the main portion of policy responsibility and resources still belongs to the national government.

Our research makes clear contributions to the current state of the art of behavioural public policy and administration (see Ewert et al, Forthcoming). We provide a behavioural insight through experimental evidence of conditions where SLBs are more likely to respond to elected politicians' policy change versus abide by existing rules in implementation decisions. While behavioural science has been discussed extensively in association with individuals, much less attention has been paid to the discipline as "a tool to improve the way government itself functions" (Sanders et al, 2018, 157-8; Lodge and Wegrich, 2016), that is, as a tool to better understand public sector behaviour. To fill this gap in the literature, we show that the behaviour of SLBs is shaped by and changes with street-level factors, such as bureaucrats' own policy dispositions and their perception of discretion in implementation. 


\section{Street-Level Bureaucrats' Implementation of Policy Change}

One of the dominant arguments in political science research concerns politicians' control of policy implementation. This view, mainly developed in the context of American politics and public policy, discusses which political institutions are more effective in controlling bureaucratic agencies which are delegated to execute the politicians' policy change. Yet, this discussion all comes from the perspective of politicians, and whether bureaucratic agencies actually perform in a way that leads to the outcome that politicians want, is not certain. This so-called "top-down" approach has two major drawbacks in understanding precisely how policy change will be implemented by SLBs. First, the top-down approach assumes that political instruments should be effective to control the bureaucracy. The literature relevant to this top-down approach discusses bureaucrats' responsiveness to political control mechanisms through rewards or punishments, as noted above. However, the other body of bureaucrat-centred approaches, the so-called "bottom-up" perspective, raises questions about the former approach and suggests that bureaucrats are not always responsive to political influence, and that street-level factors should play a more important role in their actions (Brehm and Gates, 1997; Riccucci et al, 2004; Riccucci, 2005; Meier and O'Toole, 2006). In particular, recent work on SLBs highlights the ambiguous nature of policy decisions and goes beyond the simple dichotomy of compliance versus noncompliance with policy directives (Brodkin, 2012; Gofen, 2014).

Second, executing policy change inherently includes a certain level of bureaucratic discretion (Smith, 1965; Lipsky, 1980/2010; Brodkin, 2012), but top-down perspectives of policy implementation often take a sceptical or a negative view of bureaucratic discretion (Polsky, 1993). To them, bureaucrats' discretion is mainly seen as a deviation from politicians' ideal policy preferences and thus as hindering conformance implementation. However, the truth is that some degree of bureaucrats' discretion is inevitable for successful 
implementation, as pointed out by bottom-up approaches, because the workers should be allowed room for autonomy in order to be able to manage the frontline circumstances and the limited resources available for implementation (Skolnick, 2011; Manning and Van Maanen, 1978; Maynard-Moody and Portillo, 2010; Tummers and Bekkers, 2014). In sum, an account of implementation of policy change without a clear understanding of the role of street-level factors in the politician-bureaucrat relationship remains conceptually incomplete.

Various studies have examined political and managerial controls over SLBs and their ability to affect the actual actions of SLBs (Brehm and Gates, 1997; Keiser and Soss, 1998; Brewer, 2005; Riccucci, 2005; May and Winter, 2009). These studies often find that the translation of the intentions of politicians and managers into service delivery on the frontline is affected by numerous disjunctive factors. Yet, what may add value to this literature is, reiterating May and Winter (2009), understanding of how important political or managerial influence is in the implementation equation (454) and "the behaviours of street-level bureaucrats or the channels through which that influence occurs" (456). As an increasing amount of research focusing on SLBs' behaviour suggests (Gofen, 2014; Boer et al, 2018), more in-depth research on SLBs from behavioural perspectives should add value to the current knowledge of SLBs' policy implementation.

In this article, we therefore seek to contribute a behavioural insight through experimental evidence of conditions where SLBs are more likely to respond to elected politicians' policy change versus abide by existing rules in implementation. Specifically, we examine the following two factors concerning bureaucrats' policy dispositions and perceptions that may determine the implementation of their elected politicians' policy change: 1) whether elected politicians' policy positions are shared by bureaucrats, and 2) the level of discretion bureaucrats perceive in policy implementation. In developing our hypotheses, our study builds on the assumption of the Weberian model of bureaucracy 
(Weber, 1958), where civil servants have some knowledge and skill enabling them to understand and execute policy change or a new policy (Maynard-Moody and Musheno, 2000, 2003; Hupe and Hill, 2007). Merit-based bureaucracies are not always the standard everywhere in the world, but this proviso does not undermine our logic, evolved as it is based on the modernised bureaucratic organisations we frequently observe, including American bureaucracy or the Korean case explored in this article.

\section{Ideological Congruence and Implementation of Policy Change}

The political ideology of SLBs is important, because it is conceptually identical to their policy dispositions. Since SLBs' political ideology affects how they will interpret information in implementing policies, particularly in organisations with various or vague missions (Wilson, 1989/2019), it should influence making implementation on the frontline (Keiser, 2010). Moreover, policy implementation is "part of the process between initial statement of policy and ultimate impact in the world" (O'Toole, 1986, 183), and policy change that is not consistent with SLB's policy dispositions may not be well-performed (Lipsky, 1980/2010;

O’Toole, 1986; Sabatier, 1986; Huber and Shipan, 2002). Although elected politicians might prefer to receive support from agents regardless of their ideology and characteristics (Lee and Park, Forthcoming), there is evidence that SLBs' policy positions generally play a role in interpreting and applying elected politicians' policy programs (Keiser, 1999).

Public administration and political science research commonly provides insights into how the behaviour of SLBs may be shaped by their political ideology. Keiser (2010, 249-50) suggests that bureaucrats' ideological identification, defined as "the perceptions of individuals of where they lie on a liberal-conservative continuum", has proven to be closely related to their attitudes toward diverse policy issues (Sears and Citrin, 1982) and thus should influence bureaucratic implementation. Supporting this prediction, Keiser finds indirect 
effects of SLBs' ideology on their behaviour: liberal workers were less likely to feel most accountable to U.S. taxpayers than conservative workers, and more liberal workers were not more likely to make prompt decisions on citizens' eligibility in the social security disability program $(2010,255)$. Political science research also suggests that bureaucrats may have particular policy preferences or leanings toward a certain direction of policy change during their career. SLBs are likely to be recruited with a certain level of public service motivation and policy preference to make careers in the civil service, and once in office, they may develop such policy preference (Gailmard and Patty, 2012).

The evidence of the importance of bureaucrats' ideological or policy preferences in implementation abounds in modernised bureaucracies both within and outside the U.S. In the U.S., liberal career civil servants during the Reagan administration, one of the most conservative executive governments, sometimes acted on their political ideologies and policy beliefs (Feldman, 1989; Golden, 2000). In South Korea, the primary case explored in this study, there is evidence that state bureaucrats' policy dispositions play a role in implementing elected politicians' policy change. When Kim Young-sam became the first civilian president of the country in 1993 as the candidate of the conservative Democratic Liberal Party, he introduced major economic reforms encompassing deregulation and privatisation (Baum, 2011). However, the marketising economic reform plan was resisted by pro-labour bureaucrats who preferred to maintain the status quo. To the bureaucrats who favoured more expansive economic policy and an active role for the public sector in shaping the policy, Kim's reform plans were deemed an attempt to limit their latitude.

In a word, policy change is implemented mostly by SLBs who have their own professional identity (Zacka, 2017), and SLBs may be more resistant to taking actions that are inconsistent with their ideology and preferences, dooming such change from politicians to failure (Huber and Shipan, 2002, 20; see also Linder and Peters, 1987). Therefore, we expect 
that any policy change, including a new policy, introduced by elected politicians is more likely to be implemented when it is shared by bureaucrats than when there is a discrepancy of ideological positions between politicians and bureaucrats.

Hypothesis 1. Street-level bureaucrats are more likely to implement elected politicians' policy change when the latter's political ideology is congruent with that of the bureaucrats than when they are incongruent.

\section{Perception of Bureaucratic Discretion and Implementation of Policy Change}

The other crucial element affecting SLBs' policy implementation concerns the perception of discretion in the implementation of policy change. The literature on SLBs has long emphasised their inherent discretion in policy implementation and its centrality to the implementation of policy change (Smith, 1965; Lipsky, 1980/2010; Maynard-Moody and Portillo, 2010; Brodkin, 2012). Recent research highlighting behavioural aspects of SLBs' implementation further suggests that the perceived level of bureaucratic discretion is connected with bureaucrats' policy empowerment and success in implementing policy change (Ewalt and Jennings, 2004; Van der Voet et al, 2017; Thomann et al, 2018).

The inherent nature of discretion becomes important when SLBs choose to exercise it (Skolnick and Fyfe, 1993). SLBs often strictly apply the rules for the sake of protecting themselves or when their additional effort and risk-taking in stretching or breaking the rules on clients' behalf are deemed unworthy (Maynard-Moody and Musheno, 2003; MaynardMoody and Portillo, 2010). SLBs are thus judicious and strategic in their wielding of the discretion they have at their command (Maynard-Moody and Portillo, 2010, 267), but variation may exist in treatment. Moreover, there are inequities in the extent to which SLBs are able to exercise discretion, due to differences in knowledge concerning their tasks (Sandfort, 2000; Meyers and Vorsanger, 2003), constraints within implementing 
organisations (Lynn, Heinrich, and Hill, 2000; Hill and Lynn, 2004; Brodkin, 2007, 2011), or external circumstances (May and Winter, 2009).

For this reason, implementation by SLBs involves inherent discretion, but not all workers will perceive the same level of discretion in actual execution. In this regard, recent research on how the perception of discretion plays a role in SLBs' policy implementation provides a behavioural insight. When SLBs perceive more discretion in policy implementation, the societal or client meaningfulness of a policy is more likely to increase, ${ }^{2}$ because policy programs can be aimed at specific situations for the society or the client (Tummers and Bekkers, 2014). In turn, SLBs who recognise the meaningfulness of the policy may put more effort into implementing the policy, because they are cognisant of their influence over the content of the executed policy and their interests can be reflected in the content of the new policy (Tummers et al, 2009). In brief, an increase in the perceived level of bureaucratic discretion is likely to result in their enhanced willingness to implement policy change.

We apply this line of reasoning to the relationship between the level of discretion perceived by SLBs and their willingness to implement policy change initiated by their elected politicians such as governors and mayors. In this case, the meaningfulness of such policy change is straightforward to bureaucrats as it is valuable particularly for their elected politicians. This so-called "principal meaningfulness" will help bureaucrats to increase their willingness to implement policy change in a similar way that client meaningfulness stimulates or empowers bureaucrats to execute policy change. Then the motivated bureaucrats who are aware of their influence over the content of the new policy are likely to make more efforts in implementation. It is not surprising that employees who experience

\footnotetext{
${ }^{2}$ Street-level bureaucrats need to discover the meaningfulness of new policies before they become motivated or willing to implement these policies (Tummers et al, 2009). Meaningfulness here concerns bureaucrats' perception that the new policy is valuable for society in general and for their direct clients in particular (Thomann et al, 2018).
} 
more policy powerfulness are more willing to support policy change or implement a new policy (Greenwood et al, 2002; Tummers et al, 2009). In sum, we predict that increased levels of discretion-as-perceived will lead to bureaucrats' greater willingness to execute elected politicians' policy change.

Hypothesis 2. Street-level bureaucrats are more likely to implement elected politicians' policy change when the bureaucrats perceive more discretion in implementation than when they perceive less discretion.

\section{Research Design: A Survey Experiment}

To examine the degree to which SLBs are likely to implement their elected politicians' policy change, we conducted a survey experiment of local civil service officials in South Korea's provincial and municipal governments. We test our hypotheses by employing a list experiment, a format of indirect questioning that asks survey respondents to reveal how many items on a list are relevant to them. This survey design is particularly useful to address potential concerns about social desirability bias and non-random refusals to respond. There are several reasons for our choice of this research design.

First, given that surveys are conducted at the respondents' workplace, bureaucrats may feel reluctant to disclose their true opinions and assessment of elected politicians' policy change. These settings may generate incentives to conform to prevalent social norms by giving answers favouring their governor's and mayor's policy change and likely hiding their negative opinions about it if asked directly. Moreover, due to the hierarchical structure of bureaucratic organisations and the strict civil service culture in South Korea, direct requests to evaluate their superiors' policy may also result in higher non-response rates, which, in turn, will lower the validity of our results. Finally, our survey firm negotiated access to career 
civil servants, and a format of indirect questioning should be preferable for public employees as it will attract a higher rate of acceptance among the public agents.

The basic design for a list experiment randomises respondents into control and treatment groups, where a list of control items is presented to the former group and a list of the same control items plus one treatment item (i.e. an item of interest) is shown to the latter group. Respondents are then asked to count the number of items on the list that apply to them. Through this experimental design, respondents may feel safer in disclosing their truthful answers as they are providing these in a more indirect manner. This design also enables scholars to estimate the proportion of respondents who are more likely to choose a treatment item by varying items on the list across randomly selected control and treatment groups (Blair and Imai, 2012).

In our study, we asked the following question of our control group:

When you carry out duties at work, there are many factors affecting your implementation decisions. Looking at the list below, how many of the following factors would lead you to willingly alter your existing decision for implementation of policy change? Please do not tell me which ones you agree with; only say how many factors apply to you.

1) Learn your local citizens support policy change

2) Learn your decision is not in alignment with law

3) Learn your co-workers endorse policy change

[Items are shown in a randomised order]

While there are numerous factors potentially inducing local civil servants to exercise discretion and change their existing decision for policy change, we choose as the control items internal and external settings of bureaucratic organisations that are likely to affect such decisions. Among the control items, co-workers' assessment of policy change and alignment 
between bureaucrats' decisions and law concern internal components, whereas local citizens' views of policy change are related to an external element.

According to the street-level bureaucracy literature, both bureaucrat-client and collegial interactions, as well as bureaucrats' legal perspective, may affect frontline decisions (Maynard-Moody and Musheno, 2000, 2003; Bovens and Zouridis, 2002; Riccucci, 2005; Keiser, 2010; Raaphorst and Loyens, 2020). The interaction between workers and citizens has a significant impact on bureaucratic decisions, because the workers are attentive to the identities of citizens and make decisions depending on citizens' characteristics (MaynardMoody and Musheno, 2003). Regarding collegial interactions, coworkers' impact on policy implementation is not less significant, due to their possible advisory roles. Recent case studies show that bureaucrats may consult colleagues in an attempt to "decrease subjectivism of decision making" (Raaphorst and Loyens, 2020, 50).

\section{Treatment Conditions}

In order to estimate which factors cause SLBs to be more likely to implement policy change, we split the sample of local civil servants into control and treatment groups. In the previous section, we discussed three factors that may affect implementation willingness. With the treatment condition, we examine one of the main conditions shaping SLBs' policy implementation decisions: policy change initiated by their incumbent governor/mayor.

In our study, we asked our treatment group the same question as the control group, with the exception that a treatment item relating to the incumbent governor's/mayor's policy intention is added to the list:

When you carry out duties at work, there are many factors affecting your implementation decisions. Looking at the list below, how many of the following factors would lead you to willingly alter your existing decision for implementation of policy change? Please do not tell 
me which ones you agree with; only say how many factors apply to you.

1) Learn your local citizens support policy change

2) Learn your decision is not in alignment with law

3) Learn your co-workers endorse policy change

4) Learn your governor/mayor is initiating policy change

[Items are shown in a randomised order]

\section{Sampling and Balance}

The survey was conducted in all 243 provincial and municipal governments nested in the 17 provinces of South Korea between October 2017 and February 2018, with local civil servants on the frontline who were recruited by Hankook Research, one of the largest survey research firms in South Korea. Survey samples collected by Hankook Research have been broadly used in social science research (e.g. Park et al, Forthcoming). The human research subjects aspect of our experimental protocol was approved by our university's Institutional Review Board. The sample of bureaucrats was stratified by civil service rank and recruitment type . Simple random assignment was used to distribute approximately a half of the sample to the control condition and the other half to the treatment condition. Critically for our design, the sample covers a broad range of agency settings, each of which is directed by a different governor/mayor. In total, our samples include 1,840 local civil servants. Of the completed surveys, 918 (49.9\%) came from the control group, and 922 (50.1\%) from the treatment group, making the response rates for the control and treatment conditions similar.

We have three independent variables to test our hypotheses. First, governors' or mayors' policy position is coded 1 if they are from the liberal Democratic Party, and 0 if they are from the conservative Saenuri Party. Second, SLBs' policy position is coded 1 if they express their policy position as liberal, and 0 if they express their policy position as 
conservative. Third, the level of bureaucratic discretion is coded in a five point scale (lowesthighest) from SLBs' answers to the question about the level of discretion they perceive in policy implementation (Frisch-Aviram, Cohen, and Beeri, 2018).

In our models, we also control for the following demographic characteristics and occupational backgrounds of both elected local politicians and SLB respondents:

- An education level of $0=$ completion of secondary education (or lower), $1=$ college graduate $(\mathrm{BA}), 2$ = graduate school $(\mathrm{MA})$, and 3 = graduate school $(\mathrm{PhD})$;

- A civil service $\operatorname{rank}$ of $1=\operatorname{grade} 9(\mathrm{low}), 2=\operatorname{grade} 8,3=\operatorname{grade} 7$, and $4=\operatorname{grade} 6$ (high);

- A recruitment type of $0=$ open recruitment and $1=$ centralised civil service exams;

- A civil service job category of $0=$ technical and $1=$ administrative

In Table 1, we report these characteristics by group. The $F$-test results show that no characteristics differ significantly across control and treatment groups at $95 \%$ levels of statistical significance.

[Table 1 here]

\section{Results}

In this section, we first show the observed data and mean results by group from the list experiment to compare the response across our control and treatment groups. Then, to test our propositions through more sophisticated multivariate analyses, we present the results using maximum likelihood estimators. In Table 2, we first present a summary of the observed data for the control and treatment groups. Overall, the distribution of response values is relatively normal across the two groups, indicating that flooring or ceiling effects are not likely to be a concern. Based on the observed data, the mean response is 1.84 items for the control group 
and 2.32 items for the treatment group. Examining all respondents, we see a positive and statistically significant difference in the mean responses between the treatment and control groups. This suggests that SLBs, overall, are likely to implement their governors' and mayors' policy change through exercising discretion.

[Table 2 here]

Based on these mean responses, we look into the estimated proportion of respondents who answer our treatment item affirmatively in the list experiment. According to the simple estimation based on the difference in the mean response between the treatment and control groups, the list experiment indicates that $47.6 \%$ (with the $95 \%$ confidence interval of [38.9, 56.2]) of SLB respondents chose their elected politicians' policy change as influential in changing their existing decision on policy implementation. However, our theoretical discussion makes more nuanced predictions that: 1) ideological congruence between elected local politicians and local civil servants and 2) the level of discretion local bureaucrats perceive they possess, can cause them to react differently in terms of their likelihood of implementing the politicians' policy change (see Appendix Table A1 for the results of descriptive analysis on ideological congruence). In the next section, therefore, we present our multivariate analysis of local civil servants' implementation willingness by highlighting these two factors, in order to examine how they are associated with our treatment condition.

\section{Ideological Congruence, Perception of Discretion, and Implementation of Policy Change}

For our statistical analysis of the list experiment, we use a maximum likelihood estimator devised by Blair and Imai (2012). Obtaining statistical efficiency through running a multivariate regression analysis is important for the list experiment design, because 
indirect questioning results in a loss of information (Blair and Imai, 2012). Researchers are often interested in 1) knowing how the likelihood of answering the question of interest affirmatively changes with respondents' characteristics while controlling for other variables and 2) estimating the population proportion of such respondents. In this case, maximum likelihood estimators are useful as the proportion of respondents answering affirmatively to the item of interest can be estimated under certain assumptions - 1) there is no design effect and 2) no respondents are lying — by computing the difference in the mean response between the treatment and control groups (Blair and Imai, 2012, 51-2).

In Appendix Table A2, we present the estimated coefficients and their standard errors from the fitted binomial logistic regression model where the dependent variable is whether or not their elected local politicians' policy change is considered influential for local civil servants to change their existing decision on policy implementation in Model 1. In Model 2, the dependent variable is not straightforward due to a two-step procedure required for computation. Intuitively, the treatment and control groups are analysed simultaneously, and the treatment effects are estimated through the difference in the mean response between the treatment and control groups based on the coefficients generated from the fitted binomial logistic regression model (i.e. maximum likelihood estimators).

Other than the three independent variables (elected politicians' policy position, SLBs' policy position, and the perceived level of bureaucratic discretion) introduced above, we also include as controls the characteristics of both governors/mayors and SLB respondents described above, such as demographic characteristics (age, gender, and education) and occupational backgrounds (experience in office, rank, recruitment type, and job category). Given the quantities of interest, we will present our main empirical findings through graphs. 
Estimating the difference in the mean response between the treatment and control groups based on the coefficients presented in Appendix Table A2, we test our first hypothesis by comparing the mean response of liberal and conservative SLB respondents under local governments ruled by liberal and conservative governors/mayors, respectively, with the list experiment. The treatment effect on the two SLB groups and its difference under the two governor/mayor groups are graphically described in Figure 1. Figure 1 shows estimated proportions of liberal and conservative SLBs answering the "learn your governor/mayor is initiating policy change" treatment item affirmatively and the difference in estimated proportions of the two groups. The left panel of Figure 1 displays the results under local governments headed by liberal governors and mayors, and the right panel of Figure 1 shows the results under local governments headed by conservative governors and mayors. In both panels, positive estimates of the difference indicate that conservative bureaucrats are more willing to implement their elected politicians' policy change, whereas negative estimates indicate that liberal bureaucrats are more willing to implement their elected politicians' policy change.

[Figure 1 here]

Examining the results in the two panels, we find a difference in estimated proportions that is negative and statistically significant under liberal governors and mayors, but one that is positive and statistically significant under conservative governors and mayors. In local governments headed by liberal governors and mayors, $45.7 \%$ (with the $95 \%$ confidence interval of $[34.1,57.4]$ ) of conservative and $73.5 \%$ (with the $95 \%$ confidence interval of $[66.2,80.8])$ of liberal SLB respondents considered their elected politicians' policy change influential in altering their existing decision on policy implementation. However, in local 
governments headed by conservative governors and mayors, while $69.8 \%$ (with the $95 \%$ confidence interval of $[51.4,88.1])$ of conservative SLB respondents considered their elected politicians' policy change important, about $48 \%$ (with the $95 \%$ confidence interval of $[37.2$, 58]) of liberal SLB respondents chose their elected politicians' policy change as influential in altering their existing decision on policy execution.

This finding strongly supports our first hypothesis $(\boldsymbol{H} 1)$, suggesting that whether elected politicians' policy position is compatible with that of SLBs in local governments has a powerful impact on SLBs' likelihood of implementing these politicians' new policies. This finding is in line with previous research showing that SLBs' political ideology plays a role in interpreting and executing elected politicians' programs (Keiser, 1999, 2010). It is also aligned with the literature demonstrating limited political influence on SLBs' implementation; the finding also indicates that SLBs' own policy dispositions become more important in deciding whether politicians' policy change is performed as intended or not (Brehm and Gates, 1997; Riccucci et al, 2004; Riccucci, 2005).

Further to this hypothesis, we also predicted that the degree of discretion SLBs perceive would affect their implementation of policy change in local governments. We thus test our second hypothesis by estimating the difference in the mean response between the treatment and control groups based on the coefficients presented in Appendix Table A2 and comparing such difference across varying perceived levels of discretion with the list experiment. Presented in Figure 2 are the treatment effects varying across the degree of discretion perceived by local civil servants. Figure 2 shows estimated proportions of SLBs answering the "learn your governor/mayor is initiating policy change" treatment item affirmatively, ranging from the highest 25 percent to the lowest 25 percent of our sample in terms of the level of discretion they perceive in implementation. 
[Figure 2 here]

The results in Figure 2 show a positive relationship between the levels of discretion SLBs perceive they have in local governments and their likelihood of implementing their elected politicians' policy change. For an increase in the perceived level of bureaucratic discretion from among the lowest 25 percent to among the highest 25 percent of our sample, the estimated proportion of SLB respondents choosing their elected politicians' policy change as influential in altering their existing decision increases by 11 percentage points, holding all other variables constant. This finding suggests that the more discretion bureaucrats perceive to exist in implementation, the more likely they are to exercise discretion to implement their elected politicians' policy change. Overall, the results are in line with our second hypothesis (H2). Confirming findings from existing research (Tummers and Bekkers, 2014; Thomann et al, 2018), the perceived level of discretion indeed plays an important role in SLBs' policy implementation, because their policy powerfulness, increasing with their perception of discretion, shapes their interests in supporting and implementing any policy change (Tummers et al, 2009).

In sum, the results of our analysis suggest that, despite the central government's influence over local governments in South Korea, there is ample room for exercising discretion in SLBs' policy implementation at the local level; and whether to implement elected local politicians' policy change is determined by street-level factors, such as SLBs' ideological position and their perception of discretion in implementation.

\section{Conclusion}

In this article, we seek to broaden our understanding of how SLBs respond to elected politicians' policy change. Specifically, we focus on the impact of two street-level factors on 
SLBs' behaviour: the congruence of policy position in politician-bureaucrat relationships and the degree of discretion SLBs perceive in implementation. Regarding SLBs' behaviour, we examine the extent to which SLBs are likely to alter their existing decision concerning implementation of elected politicians'policy change. For this analysis, we developed an original survey design using an indirect list experiment and employed statistical methods to estimate coefficients of interest from the survey experiment. We find that street-level factors indeed affect SLBs' implementation decisions. Local civil servants are more likely to implement their governors' and mayors' policy change when the elected politicians' policy position is more congruent with that of their own than when it is incongruent. Moreover, the treatment effects - the degree to which SLBs intend to implement the elected politicians' policy change - are greater when SLBs perceive higher levels of discretion within local agencies.

Although we endeavoured to make our experimental design as robust as possible, there are some alternative explanations for our findings on bureaucrats' implementation intentions. In terms of bureaucratic discretion, we mainly conceptualise it by focusing on the level of discretion SLBs perceive in policy implementation, but variation in exercising discretionary power may be conditional on other factors, such as their personality or their relationship with superiors and middle managers (Prottas, 1979; Brehm and Hamilton, 1996; Riccucci et al, 2004; Tummers and Bekkers, 2014; Chen et al, 2017). If SLBs are able to build closer relationships with their elected politicians or they have a personality that leads them to be more open to a change, then it will positively affect bureaucrats' willingness to implement the politicians' policy change. In addition, while the South Korean case provides useful insights into how SLBs' policy position plays a role in implementing elected politicians' policy change, confirming the importance of rank-and-file bureaucrats' preferences in exercising discretion in policy implementation (Brehm and Gates, 1997; 
Riccucci, 2005), the hierarchical nature of intergovernmental relations might limit the generalisation of our findings to federal government systems, such as the U.S.

Our study makes clear contributions to the literature on behavioural public policy and administration and provides, through experimental evidence, a behavioural insight into conditions where SLBs are more likely to exercise discretion in implementing policy change. Our analysis also speaks to the debate between top-down versus bottom-up approaches to bureaucratic discretion. Our findings give support to the latter perspective and suggest that street-level factors are important in understanding their implementation decisions, including their likelihood of executing policy change. Yet, future research should seek to explore further other political and administrative conditions beyond policy implementation settings, such as policy making processes or organisational culture and structures, to generalise these findings.

\section{Funding Details}

This work was supported by the Leverhulme Trust under Grant ECF-2018-460.

\section{Conflict of Interest}

The authors declare that there is no conflict of interest.

\section{Acknowledgements}

The authors thank Micah Gell-Redman, Elaine Housby, and GSPA faculty members at Seoul National University, as well as editor and anonymous reviewers, for their valuable comments. All errors are ours. 


\section{References}

Baum, J.R. (2011) Responsive Democracy: Increasing State Accountability in East Asia, Ann Arbor: University of Michigan Press.

Blair, G. and Imai, K. (2012) Statistical analysis of list experiments, Political Analysis, 20(1): 47-77.

de Boer, N., Eshuis, J. and Klijn, E. H. (2018) Does Disclosure of Performance Information Influence Street-level Bureaucrats' Enforcement Style?, Public Administration Review, 78(5): 694-704.

Bovens, M. and Zouridis, S. (2002) From street-level to system-level bureaucracies: How information and communication technology is transforming administrative discretion and constitutional control, Public Administration Review, 62(2): 174-184.

Brehm, J. and Gates, S. (1997) Working, Shirking, and Sabotage, Ann Arbor: University of Michigan Press.

Brehm, J. and Hamilton, J.T. (1996) Noncompliance in environmental reporting: Are violators ignorant, or evasive, of the law?, American Journal of Political Science, 40(2): 444477.

Brewer, G.A. (2005) In the eye of the storm: Frontline supervisors and federal agency performance, Journal of Public Administration Research and Theory, 15(4): 505-527.

Brodkin, E.Z. (2007) Bureaucracy redux: Management reformism and the welfare state, Journal of Public Administration Research and Theory, 17(1): 1-17.

Brodkin, E.Z. (2011) Policy work: Street-level organizations under new managerialism, Journal of Public Administration Research and Theory, 21(suppl_2): i253-i277.

Brodkin, E.Z. (2012). Reflections on street-level bureaucracy: past, present, and future, Public Administration Review, 72(6): 940-949.

Chen, C.A. Berman, E.M. and Wang, C.Y. (2017) Middle managers' upward roles in the public sector, Administration \& Society, 49(5): 700-729.

Crozier, M. (1964) The Bureaucratic Phenomenon, Chicago: University of Chicago Press.

Epstein, D. and O'Halloran, S. (1999) Delegating Powers: A Transaction Cost Politics Approach to Policy Making under Separate Powers, Cambridge: Cambridge University Press.

Ewalt, J.A.G. and Jennings Jr, E.T. (2004) Administration, governance, and policy tools in welfare policy implementation, Public Administration Review, 64(4): 449-462.

Ewert, B., Loer, K. and Thomann, E. (Forthcoming) Beyond nudge. Advancing the state-ofthe-art of Behavioural Public Policy and Administration, Policy \& Politics 
Feldman, M.S. (1989) Order without Design: Information Production and Policymaking, Stanford, CA: Stanford University Press.

Frisch-Aviram, N., Cohen, N. and Beeri, I. (2018) Low-level bureaucrats, local government regimes and policy entrepreneurship, Policy Sciences, 51(1): 39-57.

Gailmard, S. and Patty, J.W. (2012) Learning While Governing: Expertise and Accountability in the Executive Branch, Chicago: University of Chicago Press.

Gofen, A. (2014) Mind the gap: Dimensions and influence of street-level divergence, Journal of Public Administration Research and Theory, 24(2): 473-493.

Golden, M.M. (2000) What Motivates Bureaucrats? Politics and Administration during the Reagan Years, New York: Columbia University Press.

Greenwood, R., Suddaby, R. and Hinings, C.R. (2002) Theorizing change: The role of professional associations in the transformation of institutionalized fields, The Academy of Management Journal, 45(1): 58-80.

Hill, C.J. and Lynn Jr, L.E. (2004) Governance and public management, an introduction, Journal of Policy Analysis and Management, 23(1): 3-11.

Huber, J.D. and Shipan, C.R. (2002) Deliberate Discretion?: The Institutional Foundations of Bureaucratic Autonomy, Cambridge: Cambridge University Press.

Hupe, P. and Hill, M. (2007) Street-level bureaucracy and public accountability, Public Administration, 85(2): 279-299.

Keiser, L.R. (1999) State bureaucratic discretion and the administration of social welfare programs: The case of social security disability, Journal of Public Administration Research and Theory, 9(1): 87-106.

Keiser, L.R. (2010) Understanding street-level bureaucrats' decision making: Determining eligibility in the social security disability program, Public Administration Review, 70(2): 247257.

Keiser, L.R. and Soss, J. (1998) With good cause: Bureaucratic discretion and the politics of child support enforcement, American Journal of Political Science, 42(4): 1133-1156.

Lee, D.S. (2020) Executive Control of Bureaucracy and Presidential Cabinet Appointments in East Asian Democracies, Regulation \& Governance, 14(1): 82-101.

Lee, D.S. and Park, S. (2020) Ministerial Leadership and Endorsement of Bureaucrats:

Experimental Evidence from Presidential Governments, Public Administration Review, 80(3): 426-441.

Lee, D.S. and Park, S. (Forthcoming) Civil Servants' Perceptions of Agency Heads' Leadership Styles: The Role of Gender in Public Sector Organizations, Public Management Review https://doi.org/10.1080/14719037.2020.1730941 
Lewis, D.E. (2008) The Politics of Presidential Appointments: Political Control and Bureaucratic Performance, Princeton, NJ: Princeton University Press.

Linder, S.H. and Peters, B.G. (1987) A design perspective on policy implementation: The fallacies of misplaced prescription, Review of Policy Research, 6(3): 459-475.

Lipsky, M. (1980/2010) Street-Level Bureaucracy: The Dilemmas of the Individual in Public Service, New York: Russell Sage Foundation.

Lodge, M. and Wegrich, K. (2016) The rationality paradox of nudge: Rational tools of government in a world of bounded rationality, Law \& Policy, 38(3): 250-267.

Lynn Jr, L.E., Heinrich, C.J. and Hill, C.J. (2001) Improving governance: A new logic for empirical research, Washington, DC: Georgetown University Press.

Manning, P. K. and Van Maanen, J. (eds) (1978) Policing: A view from the street, Goodyear Publishing Company.

May, P.J. and Winter, S.C. (2009) Politicians, managers, and street-level bureaucrats: Influences on policy implementation, Journal of Public Administration Research and Theory, 19(3): 453-476.

Maynard-Moody, S.W. and Musheno, M.C. (2000) State agent or citizen agent: Two narratives of discretion, Journal of Public Administration Research and Theory, 10(2): 329358.

Maynard-Moody, S.W. and Musheno, M.C. (2003) Cops, Teachers, Counselors: Stories from the Front Lines of Public Service, Ann Arbor, MI: University of Michigan Press.

Maynard-Moody, S.W. and Portillo, S. (2010) Street-level bureaucracy theory, in R.F. Durant (ed), The Oxford Handbook of American Bureaucracy, New York, NY: Oxford University Press, pp. 252-277.

McCubbins, M.D. and Schwartz, T. (1984) Congressional Oversight Overlooked: Police Patrols versus Fire Alarms, American Journal of Political Science, 28(1): 165-179.

Meier, K.J. and O’Toole Jr, L.J. (2006) Bureaucracy in a Democratic State: A Governance Perspective, Baltimore: Johns Hopkins University Press.

Meyers, M.K. and Vorsanger, S. (2003) Street-level Bureaucrats and the Implementation of Public Policy, in B.G. Peters and J. Pierre (eds), Handbook of Public Administration, Thousand Oaks, CA: Sage. pp. 245-255.

Miller, G.J. and Whitford, A.B. (2016) Above Politics: Bureaucratic Discretion and Credible Commitment, Cambridge: Cambridge University Press.

O’Toole Jr, L.J. (1986) Policy recommendations for multi-actor implementation: An assessment of the field, Journal of Public Policy, 6(2): 181-210. 
Park, S., Lee, D.S. and Son, J. (Forthcoming) Regulatory Reform in the Era of New Technological Development: The Role of Organizational Factors in the Public Sector, Regulation \& Governance https://doi.org/10.1111/rego.12339

Polsky, A.J. (1993) The Rise of the Therapeutic State, Princeton, NJ: Princeton University Press.

Prottas, J.M. (1979) People Processing: The Street-Level Bureaucrat in Public Service Bureaucracies, Lexington, MA: Lexington Books.

Raaphorst, N. and Loyens, K. (2020) From poker games to kitchen tables: How social dynamics affect frontline decision making, Administration \& Society, 52(1): 31-56.

Riccucci, N.M., Meyers, M.K., Lurie, I. and Han, J. S. (2004) The implementation of welfare reform policy: The role of public managers in front-line practices, Public Administration Review, 64(4): 438-448.

Riccucci, N. (2005). How Management Matters: Street-level Bureaucrats and Welfare Reform, Washington, DC: Georgetown University Press.

Sabatier, P.A. (1986) Top-down and bottom-up approaches to implementation research: A critical analysis and suggested synthesis, Journal of Public Policy, 6(1): 21-48.

Sanders, M., Snijders, V. and Hallsworth, M. (2018) Behavioural science and policy: Where are we now and where are we going?, Behavioural Public Policy, 2(2): 144-167.

Sandfort, J. R. (2000) Moving beyond discretion and outcomes: Examining public management from the front lines of the welfare system, Journal of Public Administration Research and Theory, 10(4): 729-756.

Sears, D.O. and Citrin, J. (1982) Tax revolt: Something for nothing in California, Cambridge, MA: Harvard University Press.

Scholz, J.T. and Wood, B.D. (1998) Controlling the IRS: Principals, Principles, and Public Administration, American Journal of Political Science, 42(1): 141-162.

Skolnick, J.H. (2011) Justice without trial: Law enforcement in democratic society, Quid Pro Books.

Skolnick, J.H. and Fyfe, J.J. (1993) Above the law: Police and the excessive use of force, New York: Free Press.

Smith, D.E. (1965). Front-line organization of the state mental hospital. Administrative Science Quarterly, 10(3): 381-399.

Thomann, E., Van Engen, N. and Tummers, L. (2018) The necessity of discretion: A behavioural evaluation of bottom-up implementation theory, Journal of Public Administration Research and Theory, 28(4): 583-601. 
Tummers, L. and Bekkers, V. (2014) Policy implementation, street-level bureaucracy, and the importance of discretion, Public Management Review, 16(4): 527-547.

Tummers, L., Bekkers, V. and Steijn, B. (2009) Policy alienation of public professionals: Application in a new public management context, Public Management Review, 11(5): 685706.

Van der Voet, J., Steijn, B. and Kuipers, B.S. (2017) What's in it for others? The relationship between prosocial motivation and commitment to change among youth care professionals. Public Management Review, 19(4): 443-462.

Weber, M. (1974) The Theory of Social and Economic Organization, New York: Oxford University Press.

Weber, M. (1958) Politics as a Vocation, in H. Gerth and C. W. Mills (eds), From Max Weber: Essays in Sociology, London, Routledge. pp. 77-128.

Wilson, J.Q. (1989/2019) Bureaucracy: What government agencies do and why they do it, Basic Books.

Zacka, B. (2017) When the state meets the street, Harvard University Press. 


\section{Figures and Tables}

Table 1. Characteristics of Respondents by Group

\begin{tabular}{lccc}
\hline & Control & Treatment & $F$-Test \\
\hline Governor/Mayor Characteristics & & & \\
Policy position & 0.40 & 0.39 & $0.02(0.902)$ \\
Female (\%) & 3.27 & 3.25 & $0.00(0.986)$ \\
Age (years) & 61.85 & 61.60 & $0.69(0.405)$ \\
Education & 1.86 & 1.88 & $0.22(0.637)$ \\
Experience in office (years) & 5.5 & 5.4 & $0.89(0.346)$ \\
SLB Characteristics & & & \\
Policy position & 0.40 & 0.41 & $0.40(0.525)$ \\
Bureaucratic discretion & 3.06 & 3.04 & $0.23(0.630)$ \\
Female (\%) & 38.02 & 38.61 & $0.07(0.793)$ \\
Age (years) & 42.24 & 42.22 & $0.00(0.971)$ \\
Education & 1.02 & 1.03 & $0.79(0.373)$ \\
Rank & 2.14 & 2.14 & $0.00(0.959)$ \\
Centralised recruitment & 0.92 & 0.91 & $0.10(0.756)$ \\
Private sector exp. (years) & 1.19 & 1.32 & $1.31(0.252)$ \\
Job category & 0.73 & 0.72 & $0.27(0.604)$ \\
N & 918 & 922 & \\
\hline
\end{tabular}

Note: The table presents the mean value of each variable by group and $F$-test statstics with $p$ values in parentheses.

Table 2. Observed Data from the List Experiment

\begin{tabular}{ccccc}
\hline & \multicolumn{2}{c}{ Control } & \multicolumn{2}{c}{ Treatment } \\
\cline { 2 - 5 } Response value & Frequency & Proportion & Frequency & Proportion \\
\hline 0 & 37 & $4.03 \%$ & 33 & $3.58 \%$ \\
1 & 294 & $32.03 \%$ & 143 & $15.51 \%$ \\
2 & 364 & $39.65 \%$ & 406 & $44.03 \%$ \\
3 & 223 & $24.29 \%$ & 178 & $19.31 \%$ \\
Total & & & 162 & $17.57 \%$ \\
\hline
\end{tabular}

Note: The table displays the number of respondents for each response value and its proportion for the control and the treatment groups. 
Figure 1. Ideological Congruence and Local Civil Servants' Implementation Willingness

\section{Liberal Governor/Mayor}



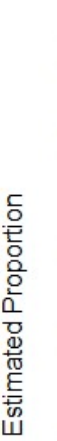

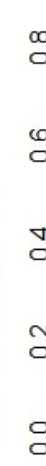

$\frac{0}{0}$

$\stackrel{1}{\stackrel{i}{i}}$

渵]
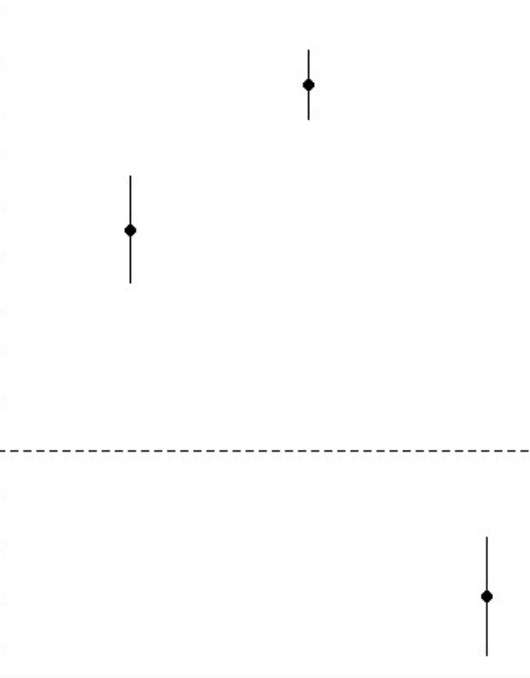

Con. Lib. $\quad \begin{aligned} & \text { Difference } \\ & \text { (Con.-Lib.) }\end{aligned} \quad$ Con. $\quad$ Lib. $\quad \begin{aligned} & \text { Difference } \\ & \text { (Con.-Lib.) }\end{aligned}$

\section{Conservative Governor/Mayor}

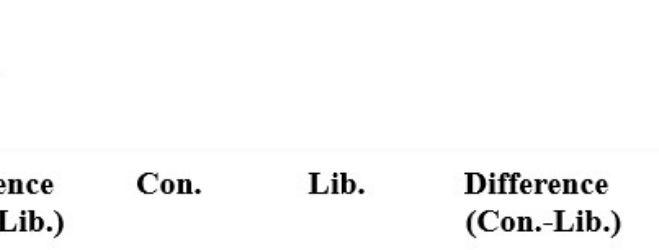

Note: Estimated proportions are based on the regression models in Appendix Table A2. 
Figure 2. Perception of Discretion and Local Civil Servants' Implementation of Policy Change

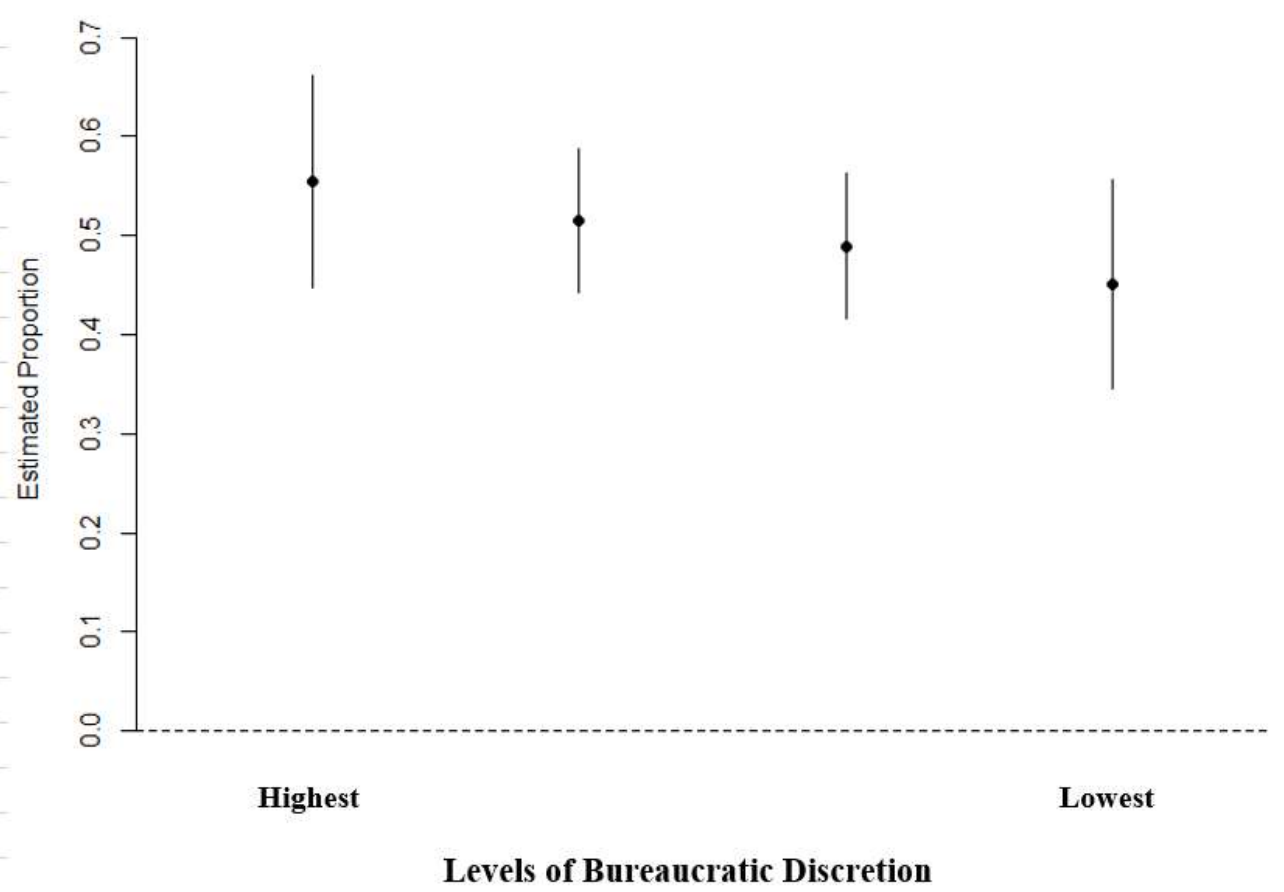

Note: Estimated proportions are based on the regression models in Appendix Table A2. 